\title{
Former Slaves on the Move: The Plantation Household, the White House, and the Postwar South as Spaces of Transit in Elizabeth Keckley's Behind the Scenes
}

\author{
Laura Gimeno Pahissa \\ Autonomous University of Barcelona \\ laura.gimenopahissa@fulbrightmail.org
}

\begin{abstract}
Travel writing has been central to the American literary canon. From all possible backgrounds, origins and spaces, religious dissenters, immigrants and others have described their travelling experiences in North America. Within this profoundly American tradition, black Americans' narratives are a special case. Most scholars agree that their personal accounts are not only autobiographical texts and political manifestos, but also travel narratives. Thus, the slaves' journey is interpreted both as a physical experience-from the plantation to a free state - and a spiritual one-from ignorance into knowledge. After Emancipation, former slaves continued publishing their life experiences, and African American women became significantly active in autobiographical writing. These women challenged previous roles, and reinterpreted themselves as independent middle class entrepreneurs. Such is the case of the author analyzed in the present article: Elizabeth Keckley. Her journey from the plantation to Washington D.C. becomes an overt challenges to the racial and gender restrictions imposed upon her and gives wings to her desire for independence. Above all, the locations she inhabits while transiting from enslavement to middle class entrepreneurship inform this crucial transformation. By means of her transit, Keckley discovers her identity not only as female member of an oppressed race, but also as an individual who can achieve and prosper beyond the barriers imposed by (white and black) male society.
\end{abstract}




\section{America, nation of travellers}

From the establishment of the British colonies in the New World, travel writing has been a central part of the American literary and historical canon. Across the ocean, from civilization to wilderness, from east to west, from south to north, religious dissenters, pioneers and immigrants have described their travelling experiences. The adventurous spirit of the American is present from the earliest texts by William Bradford, John Smith and John Hector St. John de Crèvecoeur, to the personal testimonies of later literary celebrities such as Mark Twain, Henry James or John Dos Passos. Movement has thus been - and continues to be - an essential and necessary part of American culture and identity. As Cox suggests:

Travel made the United States. As both a country and concept, America was founded on movement — of people, of ideas, of goods. Of course, international immigration has been central to American identity since the earliest European exploration, but travel within the continent likewise played a significant role in the creation and maintenance of the American nation [...] The vast majority of Europeans [...] were confined to the positions into which they had been born [...] Americans, however, were able to forge new paths for themselves by throwing off their pasts and creating their futures (Cox 2005: 1).

Travel, though, was for a long time a predominantly masculine field, since men were the ones expected to see the world and gain experience, whereas women were supposed to remain at home in control of the domestic arena. Thus, American women travellers had to subvert and challenge the "dominant social rules organized by gender, and conveyed by culture" (Wesley 1999: xii), to be able to move out of the claustrophobic and restrictive atmosphere of the home. As a result of this desire for adventure, with its resulting transgression of cultural and social restrictions, some American women, such as Mary Rowlandson, Mary Godfrey, Harriet Beecher Stowe, Edith Wharton, and Willa Cather, described their experiences in travel diaries, memoirs and travelogues.

Within this American tradition of travel writing, African Americans constitute a special case. Already in their earliest autobiographies, slaves describe their transit from Africa to the New World, whereas in eighteenth and nineteenth century accounts they narrate their escapes from the South to the North and even beyond to Canada and Europe. Their desire to flee from the plantation and to direct their journeys towards freedom makes them run away, using any means of transport. The slaves' journey is of course physical. It is also profoundly spiritual in that they do not only escape from the plantation to a free state, but they also move from ignorance into knowledge, from invisibility to self-respect. In that sense, I want to suggest that the slaves' various physical and geographical movements related both in their antebellum and postbellum narratives must be clearly differentiated between what I have chosen to call "forced" stages of transit-imposed in and through the external social and historical contextand "voluntary" stages of transit-those by which blacks assert their right to choose their own routes. In his latest work, The Making of African America: The Four Great Migrations (2010), Ira Berlin claims that, in fact, transit has been the most distinctive 
feature of African American life throughout U.S. history. He divides the history of the black people according to four main massive migrations: the transatlantic, or middle passage; the progressive movement, from the "long arc along the North American coast [...] between the Atlantic and the Appalachian Mountains" (Berlin 2010: 99) to the lower southern states and the West in order, first, to expand and diversify tobacco cultivation, and second, to create cotton and cane plantations; the massive journey to northern industrial cities in the late nineteenth and early twentieth century ${ }^{1}$; and the contemporary "global migration" of other non-U.S. African citizens into America in the late twentieth and early twenty-first centuries - with the subsequent integration problems in firmly established North-American black communities. In other words, movement has (re)defined the lives of African Americans and continues to do so. Berlin's study constitutes the culmination of a series of critical approaches which in recent years several scholars (Wesley, 1999; Cox, 2005; Stover, 2008; Smith, 2009) have undertaken in order to reassess the role of slave testimony. Thus, these critics have moved beyond describing slave stories as autobiographical texts and political manifestos, and have started studying them as travel narratives.

Women constitute a special case within the slave narrative genre. Very few African American women explained their experiences on the plantation in their antebellum texts. As Moody and Stover claim in their studies of Harriet Jacobs's Incidents in the Life of a Slave Girl (1861), black women maintained the pattern of the male slave narratives up to a point. To a certain extent their texts were the only "space where black women could document their [...] capacity to endure the horrors of slavery" (Braxton 2009: 119). However, after Emancipation former female slaves who wrote their testimonies attempted to change these dynamics. Despite having been neglected for decades, their postwar narratives ${ }^{2}$ - written between the end of the Civil War and the beginning of the twentieth century-provide a new image of the African American female that transcends highly stereotyped antebellum depictions. For these women challenging previous roles, redefining and reinterpreting themselves as independent middle-class entrepreneurs became a vital experience that brought them into whole new different moral, political and geographical spheres. Such is the case of Elizabeth Keckley, a former slave whose journey from the plantation to Washington D.C. allows her to establish new meanings for the African American woman coming out of slavery. Thus, her journey becomes an overt challenge to the racial and gender restrictions imposed upon her. It is in this process of discovering and creating her own self that Keckley transits through three key locations: the plantation household, the White House, and the South. It is my aim to show how by inhabiting these "forced" and "voluntary" spaces in her journey towards discovering herself she creates a new identity, not only as a female member of an oppressed race, but also as an individual who can achieve and prosper beyond the barriers imposed by white society. 


\section{Antebellum and postbellum slave narratives as travel books}

Slave narratives, which played a very specific social and political role within the African American community, became extremely popular in the nineteenth century. These stories, similar in pattern, helped their authors (re)create their identities as black individuals in order to "redefine their status within the human community" (Gates 1998: 2). Throughout their pages, they exposed black people's spiritual and physical suffering, as well as the institutional violation of their fundamental rights as human beings, including the right to an education. By consistently giving the subtitle "Written by himself" to their narratives, those ex-slaves who became literate challenged stereotypes and defied the widespread belief that blacks were a "less developed" race because they did not master the written word. Thus, literacy enabled them not only to articulate their position in American society, but also triggered their desire to escape as soon as they discovered, through reading, that their bondage could not be justified. Additionally, in many instances literacy actually put slaves on the move thanks to the passes they forged, which helped them to avoid being returned to the plantation by slave catchers. As Douglass said, "I wished to learn how to write, as I might have the occasion to write my own pass" (Douglass 2003: 45-47). Given literacy's central role in antebellum slave narratives ${ }^{3}$, most scholarly studies have focused mainly on this particular facet and other areas of strong interest such as language and the genre's episodic pattern. More recent studies (Wesley, 1999; Cox, 2005; Stover, 2008; Smith, 2009) have suggested that the slaves' flight towards the North may be more than a mere "journey toward freedom: a break away from the enslavement of one society and the break into the "better day' of another" (Smith 1974:13). They are, rather, a crucial necessity for the author's spiritual and textual development. As Cox points out, "travel defined their subversion [...] in order to produce a slave narrative and create a textual identity, a slave had to travel [...] travel was the necessary prelude to the publication of a narrative" (Cox 2005: 65, my emphasis). In fact, movement and transit can be found at the very roots of the peculiar institution itself: the first African slaves were shipped to the New World; they were often sold from one plantation to the other; and many attempted - and sometimes succeeded - in escaping to the North. Though many slaves lived and died on one plantation, a great many were subject to instability, moved from one place to another, from one master to another, from the cabin to the unknown liberty offered by the crossing of the Ohio River. Thus, the "slave narrative [...] generated its own subgenre of travel writing" (Smith 2009: 197).

Instances of movement abound in antebellum slave narratives and, in fact, they lead the action. It is this motion that propels the story and leads to self-evolution. As Stover highlights, it is precisely thanks to "the intricate intermediate locations"-i.e., spaces of transit - that blacks' "figurative and literal journeys" took place (Stover 2008: 73). These locations take the form of geographically meaningful spaces ("we remained in the woods during the day" [W.W. Brown 2002: 403]), and of different means of transport, which ranged from trains, boats and horses to boxes where slaves, such as Henry "Box" Brown, hid in order to be literally shipped to a free state: "I was first 
carried to the express office, the box being placed on its end, so that I started with my head downwards" (H. Brown 2007: 135).

However, I want to introduce a distinction between "forced intermediate locations" (the middle passage, the auction block) and the "voluntary" ones (the woods were slaves hid, the box used by Brown). In the first case, these forced spaces of transit are a constant reminder of the miserable conditions of slaves. They emphasize pain, suffering, and are certainly claustrophobic, inasmuch as they represent the horrible repression they suffered. As such, the narrators' language also stresses the dramatic quality of their descriptions in order to convey the involuntary nature of these movements: "I was taken away from my mother, and hired out to labor for various persons" (Bibb 2002: 442, my emphasis). Such forced intermediate spaces of transit make slaves acutely aware of the instability of their condition, as these locations mediate between their enslavement and their rising consciousness of their need to be free. The potential danger of such movement is stressed by Thomas Buchanan in his study Black Life on the Mississippi (2004), where he explains how in many statesMississippi, Missouri, Kentucky, Tennessee, Louisiana- “officers were prohibited from allowing slaves to stow away, book passage, or obtain work on steamboats unless they had their master's consent" (Buchanan 2004: 103) in order to prevent the slaves' escape.

As far as "voluntary" movement is concerned (escape from bondage), the intermediate stages involved in the process of complete liberation are endowed with a completely different meaning, because they represent the active steps on the path to freedom. In addition, each space of transit between the plantation and the North brings the end of enslavement that much closer, zones that, as Cox says, "transform the slave's movements into self-directed action and consequently destroy slavery" (Cox 2005:66). As a result, I want to suggest that the liberating event in these narratives is not so much the escape but rather the actual possibility to move and to be able to determine the direction of one's course. Political and social liberty started with the arrival in the North, but individual freedom already began with the physical motion that enabled the slave to distance himself from the master's house: "travel, in a sense, created their being, transformed them from objects into subjects" (Cox 2005: 75). In other words, self-willed transiting between geographically distinct locations, from those of bondage to those of liberty, was freedom itself. The result of their presence in voluntary spaces of transit led them to "perform several types of movement simultaneously, not only geographical, also social, racial, and intellectual" (Cox 2005: 72). The momentousness of such a turning point is shown in the language they use to describe it: "When the boat struck the mouth of the river Ohio [...] my heart leaped up for joy" (Bibb 2002: 539, my emphasis); "It was a moment of the highest excitement I ever experienced" (Douglass 2003: 93, my emphasis).

However, such voluntary intermediate locations also embody uncertainty. The slaves run away from the known world to confront the unknown beyond the boundaries of the plantation. This of course generates fear and insecurity as they face a potentially hostile world and an uncertain future: "She stopped to look about her, and ascertain if 
her pursuers were in sight [...] and, for the first time, the question came up for settlement, 'Where, and to whom, shall I go?'” (Truth 2005: 30). Many fugitive slaves describe their feelings of helplessness, thus causing their voluntary spaces of transit to strengthen the heroic dimension of their achievements. After moving through unknown lands, suffering privation, becoming disoriented and even starving, the slave progresses to the Promised Land and freedom. Unlike their time in bondage, when their owner completely controlled their every move, free movement highlights the slaves' achievement to direct their own destiny: their successful escape and voluntary transit between different stages establishes their identity as travellers and overcomes their former slave self (Cox 2005: 67).

After the end of the Civil War, some former slaves continued writing about their experiences in bondage. Confronted as they were by the new challenges posed by the abolition of slavery, they tended to idealize and romanticize their life in the peculiar institution. Many of them defined slavery as the time when their identity and character was forged, and hailed it as a defining moment. Very often these Emancipation narratives reinterpreted the relationships between masters and their slaves, and narrated past events from a radically different perspective. Part of this postbellum rewriting of life in bondage seems to have been the result of African Americans' concern with fitting into the society that emerged from the Civil War. Clearly, blacks were aware that though slavery was no longer legal, their labor was nonetheless needed and that the country - especially the South - had been drastically changed. This does not mean that former slaves somehow perverted their antebellum attitudes towards the peculiar institution and its inherent evils. On the contrary, they put their experiences to other uses, for example by claiming their central role in the rise and expansion of the United States, since it was thanks to their labor that the country's economy had prospered.

In their postbellum narratives, former slaves continued to look back to their prewar lives and followed, to a certain extent, some of the highly recognizable stages of any slave narrative, including episodes of random cruelty, the separation of families, and the plans to escape from the South. In so doing, postwar narrators maintained the dichotomy between "forced" and "voluntary" spaces of transit. However, after the war voluntary spaces of transit acquired a whole new set of meanings in the texts. For these narrators, such voluntary locations become not only the key to freedom (as is the case with antebellum texts), but also the entrance to a relatively comfortable postwar middleclass life and the creation of a new identity. This is a recurring pattern in both male and female ex-slaves who describe their achievements after 1865. In fact, while antebellum slave narratives are overwhelmingly masculine (Harriet Jacobs being the most famous exception), those following the war are slightly more diverse in terms of gender and as such one encounters the personal narratives of several former female slaves - such as Elizabeth Keckley, Susie King Taylor, and Mattie Jane Jackson. 


\section{Elizabeth Keckley's Behind the Scenes (1868): The Plantation Household, the White House and the Postwar South as Three Spaces of Transit}

Elizabeth Keckley (1818-1907) is relatively unknown among those who study African American autobiographies. Born on a plantation in Virginia, she managed to buy her freedom and went north, where she started her own business as a "modiste" and met influential people: Mrs. Jefferson Davis, Abraham Lincoln, and the family of Andrew Johnson. She worked for the Lincolns for four years, and was the First Lady's confidante. In the late 1860s, she became very popular thanks to the publication of Behind the Scenes: Thirty Years a Slave and Four Years in the White House ${ }^{5}$ (1868), an autobiography in which she described life with the First Family-i.e., her impressions of both Mary Todd and the president; Willie Lincoln's death; the president's assassination, and their financial problems afterwards. The scandal caused by some of her revelations affected her both personally and professionally, to the extent that she ended her days in a home for the destitute in Washington D.C $C^{6}$. Together with Booker T. Washington's Up from Slavery (1901), Keckley's highly controversial book is now considered to be one of the paradigmatic examples of postbellum African American autobiography. Behind the Scenes is, by turns, a slave narrative, a memoir, a biography of the Lincolns, and a historical account of her times.

Behind the Scenes shows in fifteen chapters how the author progressed from slave cabin to becoming a respectable member of the middle-class. Interestingly, this improvement is always done on her own, without the help of a man by her side. The only two men who appear to be close to her are practically silenced: on the one hand, there is her husband, an alcoholic whom she decides to abandon in order to seek her own fortune (Fleischner 2003: $142^{7}$ ), and on the other, her son-and her master'swhose role in the story is minor as the reader only briefly learns about his birth: "[he] came into the world through no will of mine" (31-32), and death after having served in the war. Her autobiography recreates the American myth of the "self-made man" and turns it into the account of the first "self-made African American woman". To do this, she divides the book into three parts: (1) her life as a slave, (2) her stay in Washington with the Lincolns, and (3) her life after the president's assassination and Mary Todd Lincoln's "old clothes scandal". All the decisions of her book articulate "forced" and "voluntary" spaces of transit which help her build and establish her identity-both as an individual and as an author-and sound her own narrative voice. Her experiences and exposure to the various crucial stages in African American nineteenth century history enable her to write a first-hand testimony and become a critic of black American life. However, in each of these clearly differentiated phases, there are three specific locations through which she travels that profoundly determine her personal evolution: the plantation household, the White House, and the postwar South.

The first part of Keckley's memoir-chapters 1 to 3-describes the protagonist's experiences in slavery. Scholars William L. Andrews and Frances Smith Foster point out that after the Civil War there was a dramatic decline in the publishing and reading of slave narratives because African Americans had been emancipated and as a result, 
the stories of blacks' bondage were not interesting anymore. However, because the stories followed a distinctly recognizable pattern that had made them very successful among white readership, former slaves such as Elizabeth Keckley decided to maintain its basic structure as the initial part to their personal postbellum memoirs. Thus, in this first section of her book, the author employed a similar design to that of antebellum texts, for it contains all the elements of the genre-e.g., the slave's birth, the traumatic separation of the family, cruel punishments, the challenges posed by the author's condition as a woman, the growing desire to leave the plantation, and her final achievement of freedom by paying her manumission - and places them together with the almost continuous and inevitable circulation of the protagonist in any slave narrative through "forced" spaces of transit such as several plantations or different geographical areas. Among all these various places through which Keckley peregrinates in the first part of her story, the master's house stands out for its being the most terrifying forced intermediate location, as it is there where she experiences, at two different stages of her life, both what it means to be an enslaved African American, and what it implies to be a black woman owned by a white man. In the first, the master's house works as a location of transit between childhood and maturity; a transition which symbolically takes place in her movement from "the rude cabin to the household" (10). A very young Elizabeth Keckley is sent to that house to take care of the master's newborn. Having been told by her mistress that she must "keep the flies out of his face, and not let it cry" (11), the inexperienced slave, who is only four years old herself, starts rocking the cradle to pacify the baby but she does it so "industriously [that] lo! Out pitched little pet on the floor" (11). As a consequence, Elizabeth is severely lashed for her "carelessness" (11) in what becomes her personal transition from innocence to a precociously full awareness of the meaning of enslavement. At the same time, she unashamedly states that this traumatic experience made her learn "those principles of character that have enabled me to triumph over so many difficulties in my life" (10). As in most slave narratives, physical chastisement goes hand in hand with psychological torment, as Keckley is repeatedly told from that moment that she will "never be worth [her] salt" (11).

The master's house also becomes a space of transit between Elizabeth's sexual innocence and her awareness of her sexual status as a black female. The protagonist is forced by one of her owner's friends - schoolmaster Mr. Bingham - to go to her master's study in order to be whipped for no apparent reason. "I am going to whip you, so take down your dress this instant" (20, my emphasis). Keckley tries to resist by fighting back but to no avail:

I resisted with all my strength, but he was the stronger of the two and, after a hard struggle, succeeded in binding my two hands and tearing my dress from my back [...] I did not scream; I was too proud to let my tormentor know what I was suffering [...] while the keen lash cut deep into my flesh (20-23).

This incident is followed by several other bloody attempts at subduing her "stubborn pride" (24, in the words of the schoolmaster). However, she suffers not only the 
teacher's repressed sexual desire in the form of flogging, which denotes the "sexual abuse implicit in the whipping of a female slave" (Fleischner 2003: 27), but also endures direct sexual abuse for four years by another man. Although Keckley keeps him anonymous ("I spare the world his name" 26), both Fleischner and Foster have identified him as Alexander Kirkland, one of her master's neighbors (Fleischner 2003: 79; Foster 1998: 26). The "coming of age" experience at the master's house culminates with the slave giving birth to a child by Kirkland: "[...] he persecuted me for four years, and I-I-became a mother" (26). Thus, she understands the supposed benefit of becoming a household slave is illusory, as this displacement to a new intermediate location unveils the terrible truth of enslavement for black women and awakens the protagonist to the fact that "sexual violation fell well within the boundaries of convention and expectation" (Fleischner 2003: 87).

In the second part of Behind the Scenes, which ranges from chapter 4 (her arrival in Washington D.C.) to chapter 11 (Lincoln's assassination), Keckley continues transiting from one place to another, taking the train to Baltimore and then back to the capital, in a scene that reminds readers of Franklin's arrival to Philadelphia, for she leaves Maryland's capital with "scarcely money enough to pay my fare to Washington" (48); visiting New York with the First Lady, and seeing postwar Richmond with the Lincolns. However, of all the important movements that Elizabeth undertakes in this part of her book, there is one that, together with her achievement of liberty, constitutes a turning point in her life: the arrival to the White House. By the time she starts working at the president's home she already has a good reputation among some of the most influential people, thanks to her skills as a dressmaker. This has allowed her to meet important people, including Verena Davis, wife of the future Confederate president, who, satisfied with Keckley's abilities and competence in her work, finally introduces her to Mrs. Lincoln. In fact, the narrator acknowledges that this had always been her ambition: "Ever since arriving in Washington I had a very great desire to work for the ladies of the White House" (61). Thus, her stay at the president's house mediates between her former self as a slave, who would "never be worth her salt" (11), and the discovery of her new potential as an independent African American entrepreneur with a relatively comfortable financial position". The White House as a "voluntary space of transit" allows her to develop her professional abilities, and works as a cathartic location in her life as it allows her to reveal how she has progressed "from being property of a struggling entrepreneur to being proprietor of a successful business" (Foster 1998: 1xxi). Besides, it is in that particular place where she not only (re)discovers herself as a woman but also becomes a commentator on the African American postbellum experience.

Keckley's relationship to Mrs. Lincoln is the most complex - and controversialelement in the second and third parts of Behind the Scenes. In fact, almost all the different episodes that affect her life in this section have to do with her employer's character and needs to one extent or another. In her four-year provisional transit through the "First Home" of the country, the author develops a profound understanding of the underlying tensions in the Lincoln family, and provides her readers with an insider's 
view of their everyday life. Rafia Zafar highlights that Keckley's focus on Lincoln's wife is so intense that it almost seems as if there was a "contest between competing and unconscious beliefs, between the desire to tell her own story and that of another" (Zafar 1997: 170). Other critics, such as Francis Smith Foster (1998), Elizabeth Young (1999), and Carolyn Sorisio (2000), have emphasized the extent to which the narrator seems to enjoy presenting herself in opposition to the president's wife, who fails to "exercise the proper discipline, honesty, and self-reliance, [the former slave] in contrast, seem[s] all the more admirable" (Foster 1998: 1xxv). Mary Todd Lincoln was profoundly unpopular in Washington society because of her "ignorance and vulgarity" (75). Merrill D. Peterson explains that "She put on "the airs of an Empress" (Peterson 1995: 50). Thus, in the several episodes which describe their relationship, Mrs. Lincoln is often shown as an ambitious and materialistic woman who loses her temper easily and who acts impulsively, while Keckley presents herself as a well-measured and discreet woman.

One of the key issues used in the narrative to distinguish between these two women's opposing behaviors is money. Whereas Keckley is very concerned about making it and spending it wisely, Mrs. Lincoln's attitude towards it is the source of much of the suffering that affects these two women's lives. While in the White House, Keckley witnesses the appalling amount of money Mary Todd Lincoln spends in order to fulfill the role of First Lady: she redecorates the presidential mansion and in less than a year she has spent the $\$ 20,000$ advance to Lincoln at the beginning of his first term (Baker 1989: 187) ${ }^{10}$. Mrs. Lincoln's comments on "the very fact of having grown up in the West subjects me to more searching observation [...] to keep up appearances, I must have money" (129) are contrasted by Keckley with passages describing freedmen's poverty:

The North is not warm and impulsive. For one kind word spoken, two harsh ones were uttered; there was something, repelling in the atmosphere, and the bright joyous dreams of freedom to the slave faded-were sadly altered, in the presence of that stern, practical mother, reality. Instead of flowery paths, days of perpetual sunshine, and bowers hanging with golden fruit, the road was rugged and full of thorns, the sunshine was eclipsed by shadows, and the mute appeals for help too often were answered by cold neglect. Poor dusky children of slavery [...] the great masses of the North learned to look upon your helplessness with indifference-learned to speak of you as an idle, dependent race (93-94).

Thus, the author is hinting at the difficult balance that former slaves who massively emigrated to the North had to maintain in order to survive and contrasts it to the irresponsible behavior of the First Lady. Even though Keckley almost never overtly passes judgment on Mrs. Lincoln's actions and words, she does often compare Mrs. Lincoln to the president. Right from the beginning, Keckley describes him as a kind, approachable gentleman, a "man of the people" (64). Unlike his wife, who cannot control her emotions and who always reacts excessively to everything, the president is discreet and dignified even when in pain, and stands out as the best leader for both his family and the nation. Keckley clearly aligns herself with the president, whom she 
almost blindly venerates. After his second inauguration, for example, the former slave asks the First Lady whether she can have one of the President's gloves as a keepsake to which Mary Todd replies: "You have some strange ideas, Lizabeth. Never mind, you shall have the glove" (144). According to Lynn Domina, Keckley's description of President Lincoln's model behavior and mythical status seems to aim at representing herself "as a mimetic example of the dead heroic president" (Domina 1997: 140).

With the assassination of this honored man ("No common mortal had died. The Moses of my people had fallen in the hour of his triumph", 175), Keckley's stay at the First Home ends. Instead of remaining with Mary Todd, Keckley decides to move on, and continue enjoying her transition between her past as a slave and the new identity that she is shaping for herself. Just as the plantation household had defined the change between her childhood and purity to the realization of her social status as a slave and as a black woman, the White House enacts a further transformation in her movement towards self-knowledge and professional fulfillment.

The last third of Behind the Scenes - chapters 11 to 15-narrates how Mrs. Lincoln departed the White House completely alone; her attempts at selling her wardrobe; and Keckley's own trip to the South. It is precisely this last intermediate location in the modiste's postbellum life that becomes a crucial episode in the book, as the author's return to her origins is depicted as a moment of joy, reconciliation, and of profound irony.

In her last transit between her old identity as a slave and her new emancipated self, Keckley tries to come to terms with her past by going to the place where she grew up. This time, her visit to the South and the old plantation is a voluntary movement carried out by a woman who struggles between the painful remembrance of her bondage and the acceptance of her own origins. Historian Ira Berlin suggests that among former slaves this was a very common emotional reaction: "the firm connections necessitated by chattel bondage created a profound respect and even affection for place and the men and women connected to those places" (Berlin 2010: 26). In fact, Keckley follows a similar argument when she explains to her friends in the North why she wishes to travel to the South:

You forget that the past is dear to everyone, for to the past belongs that golden period, the days of childhood. The past is a mirror that reflects the chief incidents of my life. [...] These people are associated with everything that memory holds dear, and so long as memory proves faithful, it is but natural that I should sigh to see them once more [...] You do not know southern people as well as I do-how warm is the attachment between master and slave (217).

Similar episodes can also be found in other Emancipation narratives, such as James Lindsay Smith's Autobiography of James L. Smith (1881), and Frederick Douglass's Life and Times of Frederick Douglass (1881), where ex-slaves travel to their previous southern homes and masters. According to Andrews, this 
[...] points up a psychological complexity in the Afro-American slave narrative tradition that can be too easily ignored. The attitude of the ex-slave toward her or his past in the South is complicated by the obvious fact that the antebellum past is the locus of much pain as well as some pleasure in recollection. The antebellum slave narrator concentrated on the painfulness of remembering the Southern past; the image of the Southern past for most slave narrators before 1865 stresses absence, deprivation, want-what was not there, what was stolen and refused by whites, what was denied by the institution of slavery [...] Keckley insists [...] that the past is not something that can or should be selectively forgotten. Everything about her Southern past, the good and the bad things, is interwoven" (Andrews 1989: 13, my emphasis).

Keckley's need to revisit the South is a process which is hardly understood by her friends: "How can you have a kind thought for those who inflicted a terrible wrong upon you by keeping you in bondage?" (217). But that return is crucial for her acceptance of her past. According to Andrews, part of this need comes from the realization that it was "no longer in the best interest of black Southerners, to feed the sectionalism of the past" (Andrews 1989: 12). However, I suggest that rather than seeking reconciliation with her masters, Keckley needed to make peace with her present self and her often traumatic memories as part of the individual healing process and personal evolution of the ex-slave. Thus, by revisiting the places of her childhood she goes on a spiritually cathartic journey, as a result of which lost memories both happy and painful come flooding back, setting the stage for her coming to terms with her prewar life.

At the same time, though, the former slave's journey to the South is not performed in "antebellum terms". It is certainly very relevant to point out that Keckley's triumphant arrival to the plantation ("'It is Lizzie! It is Lizzie!' was the happy cry from all parties", 222) is done as a successful middle-class entrepreneur whose economic position is far better than her former masters'. This woman, who was repeatedly told she would "never be worth her salt" (11), has now achieved a respectable status in Washington society, unlike her enslavers, who, in an ironic reversal of roles, now toil in the fields and are in charge of all household chores ${ }^{11}$. As one of the members of the family complained in a letter to the former slave: "I have had to be at times dining-room servant, housemaid, and the last and most difficult, dairymaid" (228). The narrator seems puzzled at most white women's lack of skills, describing how "pitifully illprepared for the postwar era" (Sorisio 2000: 23) they were, unlike her and other exslaves whose work on the plantation made them ready to face all kinds of challenges. In fact, this scene seems to echo Keckley's remarks at the beginning of the book when she asserts that she had learned some "principles of character" (10) which helped her survive enslavement and prosper in her postbellum life. Thus, in this third part in her autobiography, Keckley defines herself in relation to her past, both joyful and painful, and seeks to place freed blacks under the light of achievement. 


\section{Conclusion}

The writings of former slaves demonstrate that transit in antebellum America was crucial to the formation of a black sense of self. Either by means of those "forced" changes (slaves sold from one master to another) or by the "voluntary" transits (escape from slavery and, after the war, movement to better living conditions) relocation was the basis of all black experience in America:

In slavery and freedom, black people twisted the meaning of movement and place, transforming places of repression into places of liberation and places of confinement into routes of escape (Berlin 2010: 20).

Since Emancipation opened up a world of possibilities, travelling during the postbellum period provided African Americans with further chances to redefine and recreate themselves. In this sense, Elizabeth Keckley's Behind the Scenes (1868) becomes a paradigmatic example of the new African American and, more precisely, of the new black woman who emerged from slavery. Her story-largely ignored and almost exclusively studied by most critics in terms of her relationship to Mary Todd Lincoln-is one of "unwavering determination to prove herself in whatever she undertook, particularly in those aspects of her life that involved career" (Andrews 2005: viii) and becomes the narrative of the first African American self-made woman. Keckley's achievements and failures are shaped both by her "forced" and "voluntary" transits between three intermediate locations which determine a series of key phases in her life: the master's house in which the young Elizabeth loses her innocence; the White House where she succeeds professionally; and, when going back to her origins, she makes peace with her past. Thus, by being in constant movement, the former slave is able to challenge racial and gender constraints, reinvent herself, and create a path towards full citizenship.

\section{Notes}

1. See also: Wilkerson, I. The Warmth of Other Suns: The Epic Story of America's Great Migration. New York: Random House, 2010.

2. In David Blight's A Slave No More: Two Men who Escaped to Freedom. Orlando: Harcourt, 2007, the author uses the term "emancipation narrative" to refer to the same tradition in post-1865 writing that William L. Andrews labels as "postbellum slave narrative" in his article "Reunion in Postbellum Slave Narrative: Frederick Douglass and Elizabeth Keckley", Black American Literary Forum, 23:1, 5-16, 1989. I will use both terms interchangeably in the present article.

3. In fact, literacy still has very often continued to exert a powerful fascination in many African American autobiographies written after Emancipation and into the twentieth century; e.g., Susie King Taylor's Reminiscences of My Life in Camp (1902), William Pickens's Bursting Bonds: The Autobiography of a New Negro (1923), Zora Neale Hurston's Dust Tracks on a Road (1942), and Malcolm X's The Autobiography of Malcolm X (1965). 
4. In Francis Smith Foster's edition of Keckley's text, she makes it clear that the word modiste is the term Keckley always used to refer to her job because it implied being an expert on fashion (Foster, 1998: 49).

5. All quotations are from Francis Smith Foster's edition of Behind the Scenes, published in 1998 by R.R. Donnelley and Sons.

6. In fact, both Mary Todd Lincoln and her son Robert tried to prevent the publication of Keckley's Behind the Scenes.

7. It is important to note that in Fleischner's book, Mrs. Lincoln and Mrs. Keckly: The Remarkable Friendship Between a First Lady and a Former Slave (2003), the former slave's name is spelled "Keckly" and not "Keckley". Fleischner argues her choice by saying that the slave's signature on her application for her son's war pension reads "Keckly" instead of "Keckley". However, the latter is the most commonly used spelling in all other secondary literature and even in the different editions of Behind the Scenes. Therefore, the latter form is the one used in this article.

8. The "old clothes scandal" makes reference to Mary Todd Lincoln's determination to sell her wardrobe in 1867 as a result of her serious financial problems.

9. Rafia Zafar interestingly points out that a good subtitle for Behind the Scenes would be "employed by herself" as "it is by economic skills that [...] Keckley wins her legal [freedom]" (Zafar 1997:158).

10. Because of Mary Todd Lincoln's careless behavior, Keckley is forced again to enter into a series of journeys with the First Lady in the third part of the book in order to help her sort out the financial trouble she has caused with irresponsible spending. The First Lady ended up in the hands of two commission brokers named Keyes and Brady who tried to maximize their profits while "helping" Lincoln's widow.

11. Throughout the South, most master and mistresses had to take over all domestic tasks once the war was over. Behind the Scenes is not the only postbellum text where this social and economic role reversal has been portrayed. Other examples are Mattie Jane Jackson's The Story of Mattie Jane Jackson: Her Parentage, Experience of Eighteen Years in Slavery, Incidents during the War, Her Escape from Slavery: A True Story (1886), and James Lindsay Smith's Autobiography of James L. Smith (1881).

\section{References}

Andrews, William L. (1989): "Reunion in the Postbellum Slave Narrative: Frederick Douglass and Elizabeth Keckley". Black American Literature Forum, 23 (1): 5-16.

Berlin, Ira (2010): The Making of African America: The Four Great Migrations. New York: Penguin Books.

Bibb, Henry (2002): "Narrative of the Life and Adventures of Henry Bibb, an American Slave, Written by Himself". 1849. Ed. William L. Andrews. Slave Narratives. New York: Library of America.

Braxton, Joanne M. (2009): “Autobiography and African American Women's Literature". Angelyn Mitchell and Danille K.Taylor (eds.) Cambridge Companion to African American Women's Literature. Cambridge and New York: Cambridge University Press.

Brown, Henry "Box" (2007): "Narrative of Henry 'Box' Brown”. The Great Escapes: Four Slave Narratives. 1849. New York: Barnes and Noble. 
Brown, William Wells (2002): "Narrative of William Wells Brown, a Fugitive Slave". Ed. William L. Andrews. Slave Narratives. 1847. New York: Library of America.

Buchanan, Thomas C. (2004): "Boats against the Current: Slave Escapes on the Western Rivers". Black Life on the Mississippi. Chapel Hill and London: The University of North Carolina Press.

Cox, John D. (2005): "Moving Slaves: Frederick Douglass, Solomon Northup and the Politics of Travel in Antebellum America". Travelling South: Travel Narratives and the Construction of American Identity. Athens and London: The University of Georgia Press.

Domina, Lynn (1997): "I Was Re-elected President: Elizabeth Keckley as Quintessential Patriot in 'Behind the Scenes, or Thirty Years a Slave and Four Years in the White House"'. Ed. L. Coleman. Women's Life-Writing: Finding Voice, Building Community. Bowling Green: Bowling Green State University Popular Press.

Fleischner, Jennifer (2003): Mrs. Lincoln and Mrs. Keckly: The Remarkable Story of the Friendship between a First Lady and a Former Slave. New York: Broadway Books.

Foster, Frances Smith (1979): Witnessing Slavery: The Development of Antebellum Narratives. Westport: Greenwood Press.

Gates, Henry Louis and William L. Andrews (eds.) (1998): Pioneers of the Black Atlantic. Washington: Civitas.

Keckley, Elizabeth (1998): Behind the Scenes: Thirty Years a Slave, and Four Years in the White House. 1868. Ed. Francis Smith Foster. Chicago: R.R. Donnelley and Sons.

- (2005): Behind the Scenes: Thirty Years a Slave, and Four Years in the White House. 1868. Ed. William L. Andrews. New York: Penguin Books.

Moody, Jocelyn (2009): "African American Women and the United States Slave Narrative". Angelyn Mitchell and Danille K.Taylor (eds.) Cambridge Companion to African American Women's Literature. Cambridge and New York: Cambridge University Press.

Peterson, Merrill D. (1994): Lincoln in American Memory. New York: Oxford University Press.

Smith, Sidonie (1974): Where I'm Bound: Patterns of Slavery and Freedom in Black American Autobiography. Westport: Greenwood University Press.

Sorisio, Carolyn (2000): "Unmasking the Genteel Performer: Elizabeth Keckley's Behind the Scenes and the Politics of Public Wrath". African American Review 34 (1): 19-38.

Stover, Johnnie (2003): "A Patchwork of Cultures: Journeys of African American Women Autobiographers". Rhetoric and Resistance in Black Women's Autobiography. Gainesville: University Press of Florida.

Taylor, Susie King (1992): Reminiscences of my Life in Camp with the 33rd U.S. Colored Troops, Late 1st South Carolina Volunteers: A Black Woman's Civil War Memoirs. 1902. Princeton and New York: Markus Wiener Publishing, Inc.

Truth, Sojourner (2005): Narrative of Sojourner Truth. 1850. New York: Barnes and Noble.

Wesley, Marylin C. (1999): “A Woman's Place: The Politics of Space in Harriet Jacob's Incidents in the Life of a Slave Girl". Secret Journeys: The Trope of Women's Travel in American Literature. Albany: State University of New York Press.

Young, Elizabeth (1999): "Black Woman, White House: Race and Redress in Elizabeth Keckley's Behind the Scenes". Disarming the Nation: Women's Writing and the American Civil War. Chicago: The University of Chicago Press.

Zafar, Rafia (1997): "Dressing Up and Dressing Down: Elizabeth Keckley's Behind the Scenes at the White House and Eliza Potter's A Hairdresser's Experience of High Life". We Wear the Mask: African Americans Write American Literature 1760-1870. New York: Columbia University Press. 